\title{
A WARTIME STAMPEDE: RENEWING A SOCIAL CONTRACT AFTER THE GREAT TUNNEL DISASTER OF CHONGQING
}

\section{Ying-kit Chan}

Princeton University

Although the Second Sino-Japanese War (the "War") ended many decades ago, hostilities between China and Japan are still raw in the memory of many Chinese people, even though most of them did not directly experience the War. In particular, the Great Bombing of Chongqing - the indiscriminate, sustained bombing of the Nationalist provisional capital by Japanese warplanes from 1938 to I 943 - has been retrieved from the archives as a significant event. Subsumed under the narrative of the Great Bombing, Chongqing's Great Tunnel Disaster (the "Disaster"), following a prolonged Japanese air raid on June 5, I94I, resulted in some of Nationalist China's heaviest civilian casualties. This article discusses the Disaster in detail, suggesting that at the time, it was viewed more as a human-induced "stampede" than as a Japanese "war atrocity" when the Chinese public took to the press and condemned the Nationalist government for its inability to prevent, manage, and mitigate the Disaster's effects. Chinese civilians were attempting to renew and revise a traditional social contract of disaster, according to which the state was responsible for providing adequate relief to victims, by accusing the Nationalist government of callousness, incompetence, and negligence.

Keywords: air-raid shelter; Chongqing Great Tunnel Disaster; disaster studies; Second Sino-Japanese War; social contract

\section{INTRODUCTION: DISASTER DURING THE GREAT BOMBING}

On March 30, 2006, forty survivors of the World War II Japanese bombing of Chongqing (Chungking) went to the Tokyo District Court to sue the Japanese government. They demanded an apology and compensation for the hurt and pain that they had endured during the War. On February 25, 20I5, the Tokyo District Court ruled against the survivors, who then appealed. ${ }^{\mathrm{I}}$ On September 3, 20I5, to politicize the lawsuit and support the

I “Kongxi yihen: Chongqing dahongzha minjian dui Ri suopei de quzhe licheng 空襲遺恨: 重慶大轟炸民間對 日索賠的曲折歷程” “"Air-raid sorrows: ordinary folk seek compensation from Japan for the great bombing of Chongqing”), Beijing ribao 2015. For an overview of the lawsuit, see Maeda 2009, pp. I35-36. 
plaintiffs in their appeal, the Chinese government invited approximately twenty survivors to its largest-ever military parade, which marked the seventieth anniversary of the end of the War. ${ }^{2}$

Survivors of Chongqing's Great Tunnel Disaster (Chongqing dasuidao can'an 重慶大隧道 慘案, or the "Disaster"), which occurred on June 5, I94I, have invoked their memories of the event on various occasions. Every year since I998, Chongqing's municipal government has sounded an air-raid siren on the anniversary to commemorate the Disaster's victims, reminding the Chinese of the horrors of war. Upon hearing the siren, the inhabitants stop whatever they are doing to observe a moment of silence for the dead. School children take oaths to remember the "national humiliation." 3 Both the reenactment of historical events and the preservation of the Tunnel site for commemorative purposes have left painful, tenacious memories, along with a deep psychological imprint on the Disaster's survivors and their descendants. ${ }^{4}$ Perhaps this is yet another harrowing reference to the significance of nationhood in present-day East Asia, where geopolitical conflicts between China, Japan, and Korea over historical legacies and territorial claims continue unabated. 5

The "Great Bombing of Chongqing" (Chongqing dahongzha 重慶大轟炸) took place between February I938 and August I943, with more than 9,500 aircraft dropping approximately 2 I,600 bombs on the wartime capital. Approximately I5,000 Chinese died and more than 20,000 were injured by the aerial bombardments. ${ }^{6}$ Although the Great Bombing-considering its destructive capacity and mechanized killing-enabled the inhabitants of Chongqing to imagine themselves as active war participants comparable to frontline troops, 7 the bombardments' impacts were uneven, and class (and to a lesser extent, gender) were implicated in that unevenness. Ordinary residents-people from the middle and lower classes-lacked access to the well-equipped underground shelters of senior government officials and wealthy businessmen, and suffered disproportionally high casualty rates. ${ }^{8}$ In other words, the varying standards of bomb shelters rendered the invisible concept of social class concrete, strengthening Chongqing's social hierarchy. ${ }^{9}$ On a slightly brighter note, the aerial attacks allowed the Nationalist state to remake Chongqing, covered with rubble and debris, in the image of modern Shanghai. ${ }^{\text {1o }}$

The importance of contemporary Chongqing as a major economic and transportation hub in China's western interior has spawned a great deal of Chinese-language literature

2 “Chongqing dahongzha shouhaizhe guan yuebing: dui Ri suopei shiyue jiang zai qihang 重慶大轟炸受害者 觀閱兵: 對日索賠十月再啟航” “Victims of the great bombing of Chongqing attend military parade: seeking compensation from Japan again in October”), Zhongguo xinwen wang 2015.

3 “Chongqing juxing Chongqing dahongzha jinian huodong 重慶舉行重慶大轟炸紀念活動” (“Chongqing holds commemorative service for the great bombing of Chongqing”), Xinhua wang 2015.

4 Tan 20I5, p. II.

5 The literature on Sino-Japanese antagonism in modern times is substantial. See, for example, Yoshida 2006; Dudden 2008; and Wang 2012.

6 The statistics are from Tow 20I I, pp. 256-57.

$7 \quad$ Ibid. p. 28I.

8 Chang 20II, pp. 59-79.

9 Tan 20I5, p. 5. 
in recent years on the city's contributions to the almost "forgotten" Chinese war effort. ${ }^{\mathrm{II}}$ The Chinese government sponsors the Dahoufang 大後方 (the "Great Rear," referring to China's western region not occupied by the Japanese during the War) Project and the publication of archival documents from the Chongqing Municipal Archives. However, the articles, books, and dissertations that mine these newly available resources are largely descriptive and under-conceptualized. ${ }^{\mathrm{I} 2}$ One of the books published under the Project, perhaps to indict the Japanese for their wartime actions in China, is entitled Zhengren zhengyan 證人證言 (Testimonies of Witnesses). That work is a collection of anecdotes recounting individual experiences and hardships under the Great Bombing. ${ }^{\mathrm{I3}}$

In short, although the existing scholarship details the Great Bombing, it mentions Chongqing's Great Tunnel Disaster only in passing. Scholars have viewed the Disaster as part of the Great Bombing, an outcome of one of the countless air raids on Chongqing during that time. Their opinion differs from what residents of wartime Chongqing, and the Chinese public in general, had imagined the Disaster to be: a largely human-induced disaster that was the result of the Nationalist government's failure to address serious deficiencies in the provision of both public air-raid shelters and material to make those shelters a safe and reliable refuge. These were also problems faced by European warzones in the Second World War, when social differences also emerged because of contrasts in wealth, with the working class suffering disproportionately from the consequences of bombings. The damage and horrors of the War transformed the Chinese and European societies that experienced it, with the traditional elites suffering drastic, irrevocable losses in status. The elites' failure to protect their nation was viewed by the rest of society as a sign of their incompetence and lack of preparation for a conflict that seemed inevitable, at least in hindsight. ${ }^{4}$

In Western Europe, mobilized civilians, who were not immune to enemy air raids, contributed to the national war effort. After victory was achieved, they demanded a comprehensive welfare system to support all citizens in their time of need as a form of compensation for their wartime sacrifices and suffering. ${ }^{15}$ In China, the Nationalist state collapsed shortly after the War, and the Chinese Communist Party led the people in a "continuous revolution" that lasted into the I970s. ${ }^{\mathrm{I} 6}$ After the I980s, revised history textbooks in Japan and the need to adopt a nationalistic posture to retain popularity in the face of opposition to economic reforms, among other reasons, drove the Chinese government to reassess the role of the Nationalists during the War, reminding Japan about its conduct during that time. The Nationalists, the "class enemies" of the past, are now favorably perceived as having made positive contributions despite their limitations and shortcomings. ${ }^{17}$

II Mitter 20I3.

I 2 For an excellent overview of the relevant Chinese literature, see Zhou, Chang, and Gong 20I4, pp. 6I I-27.

I3 Zhou, ed. $201 \mathrm{ra}$.

I4 Lary 20Io, p. 6.

I5 A considerable body of literature exists on the role that civilians played in wartime Europe and how it influenced postwar policymaking. See, for instance, Baldoli, Knapp, and Overy, eds. 20I I; Overy 20I3; and Overy, ed., 2015.

I6 Mittler 20I3.

I7 Yoshida 2006, pp. I02-I3. See also Mitter 2010, pp. 85-95. 
Chongqing's Great Tunnel Disaster became subsumed under the Great Bombing narrative, which-like the Rape of Nanking - is a recent reconstruction designed to promote nationalism in China. ${ }^{18}$

This article suggests that the Great Tunnel Disaster of Chongqing was not always viewed as a symbol of Japan's wartime aggression, as it is now. Back then, ordinary Chinese distinguished the Disaster from other events and outcomes of Japanese air raids on Chongqing. They viewed it as a stampede that had occurred because of the Nationalist government's actions (or lack thereof). The Disaster was human-induced and its victims died "unnatural deaths." I9 The indirect causes of the Disaster included prolonged aerial bombingsJapanese fighter planes escorted the bombers and harassed Chongqing for more than five hours - on the fateful night of June 5, I94I, and panic among the people fleeing in fear in the Great Tunnel. ${ }^{20}$ Nevertheless, the idea that the Nationalist government (and more specifically, the municipal authorities in charge of building the air-raid shelters and the Air Defense Command responsible for managing them in an air raid) were directly responsible for the Disaster was extremely strong in Chinese public consciousness in the Disaster's immediate aftermath. This article focuses on perceptions of the Disaster by people who professed to sympathize with the survivors and the victims, not on the actual measures designed by the Nationalist government to manage and provide relief from the Disaster. This article highlights the contemporary debate over accountability and responsibility for the Disaster, which, according to the public opinion at the time, revealed the government's malfeasance in harming its own citizens and its reluctance to relieve victims of the stampede-both of which were manifestations of its callousness.

Having experienced, either directly or indirectly, a multitude of natural and warinduced hazards in the I930s and I940s, the Chinese developed a "culture of disaster" by integrating the constant threat of disaster into the schema of everyday life. Hazards are physical phenomena, but disasters take place because of a community's political structure and social order that expose its constituents to the dangers inherent in natural or human-induced disturbances. ${ }^{2 \mathrm{I}}$ Residents of wartime Chongqing were accustomed to air raids, but the Disaster appalled them amid reports of the government's indifference, negligence, and callousness. In the weeks following the Disaster, critics accused the government of mismanagement. Outwardly, they reasoned that the government could have prevented the high death toll if it had secured adequate provisions for the air-raid shelters and that it should have provided the victims with immediate material relief. Implicitly, they sought to renew the traditional social contract of the state relieving the people in their time of need after a disaster.

Rana Mitter has identified a "callous streak in the government's collective psyche, leading officials to regard the lives of individuals as expendable."22 Based on the public's

\footnotetext{
I8 Yoshida 2006, p. 4.

I9 Bessel 20I5, p. 327.

20 Guo 20I5, p. II.

2 I Bankoff 2003, p. 3 .

22 Mitter 20I3, p. I59. For more on the callousness of the Nationalist government during the War, see Lary 2004, pp. I43-70.
} 
responses to the Disaster, we see that at that time, the Chinese also recognized the government's relatively callous disregard of civilian lives-a breach in the morality of conduct in war. Although the Nationalist government ran successful propaganda campaigns that won the support of the foreign press for its war effort, ${ }^{23}$ it also had to shed its domestic image of callousness and appease the populace when disaster hit home in its wartime capital. Because of their vulnerability during war, ordinary civilians (pingmin 平民), a category of people who existed in opposition to soldiers and did not exist during imperial times, posed new political and social challenges to the wartime government, which had to prove to the Chinese people that their protection was total in a total war.

\section{DISASTERS IN WARTIME CHINA}

Despite the high prevalence of natural disasters in twentieth-century China, ${ }^{24}$ historical research on disasters, observes Andrea Janku, remains a relatively new field in Chinese studies. ${ }^{25}$ Historians have focused on the famines in Northern China and Chiang Kaishek's (I887-1945) decision to breach the Yellow River dikes in June I938 (which led to a famine in Henan in I942-I943) to hold Japan's military advance to Central-West China. Recent studies have revealed that contemporary accounts of China's disasters represented foreign caricatures of a backward China ruled by a government whose callousness and incompetence in disaster management and relief aggravated the impact of those disasters on civilian victims. ${ }^{26}$ Bertrand Russell (I872-1970), who visited China on a speaking tour in I920-I92I, remarked that the "callousness of the Chinese"-for their lack of a humanitarian impulse to relieve the famine in North China- "is bound to strike every Anglo-Saxon."27 Theodore H. White (I9I5-I986), who perceived the wartime Nationalist government as corrupt and ineffectual, recorded the horrors of the Henan famine and blamed the local authorities for not alleviating it. ${ }^{28}$

The most recent scholarly literature has also established that disaster victims were indeed helpless-but not as helpless as we have imagined. Native-place and religious associations with origins in late Qing times formed relief regimes that functioned like local governments after the collapse of social order. ${ }^{29}$ The internationalization of disaster relief in twentieth-century China also witnessed collaboration between Christian missionaries,

23

24 党
Wei 20I4, pp. II8-43.

A few major disasters should concern us here: I) the North China famine of I920-I92I, which affected Henan, Shaanxi, Shandong, Shanxi, and Zhili (Hebei), had an estimated mortality of 500,000; 2) the Chinese famine of I928-I930, which affected Chahar, Gansu, Hebei, Henan, Rehe, Shaanxi, Shandong, and Suiyuan, had an estimated mortality of up to Io million; 3) the Yellow River flood of 1938-I947, which displaced and killed millions in Anhui, Henan, and Jiangsu; and 4) the Henan famine of 1942-I943, which led to approximately 2 million deaths. For these statistics, see Fuller 20I5, p. I54 and Muscolino 20I5, p. 2.

On the famines in twentieth-century North China, see: Li 2007; Janku 20I2, pp. 227-60; and Fuller 20II, pp. 453-72. On the Yellow River floods, see: Lary 200I, pp. 205-6; Edgerton-Tarpley 20I4, pp. 447-69; Muscolino 20I5; and Pietz 20I5.

Russell I922, p. 22 I. For an elaboration of Russell's impression of China, see Fuller 20I I, pp. 465-66.

White and Jacoby I946, pp. I66-78. On the context of White's observations, see Lary 2004, pp. I60-6I.

Fuller 2015, pp. I46-65. See also Will I990 and Li 2007. 
global charitable organizations, local philanthropists, and overseas Chinese in rendering aid to disaster victims. ${ }^{\circ}$ Scholars have claimed that the Second Sino-Japanese War (I937-I945) nullified imperial China's social contract between the state and the people (i.e., that it would help the people when they were hit by disasters); in times of distress, people expected at least a modicum of relief from the state. Indeed, the War led the Nationalist government to prioritize military exigencies over civilian needs. This meant making strategic decisions such as breaching river dikes, engineering a flood to stem advancing troops, and collecting land taxes in kind (i.e., in grain instead of cash) even from disaster-stricken areas to feed "diseased, poorly motivated, and hungry" frontline soldiers. ${ }^{3 \text { I }}$ To compound victims' woes, continuous fundraising campaigns across China had the unintended consequence of de-sensationalizing the disasters, gradually reducing the amount of aid and donations. ${ }^{32}$ Chinese newspapers, because of both government censorship and their self-conception as the medium of anti-Japanese nationalism, championed nationbuilding and total war efforts and downplayed the suffering caused by disasters. ${ }^{33}$ Nevertheless, Chongqing's Great Tunnel Disaster showed that the social contract of state relief in a disaster remained alive in the public consciousness during the War. Precisely because the Nationalist government became aware of its reputation for callousness, it maneuvered itself into shouldering responsibility to redeem itself and to maintain the façade of national solidarity for foreign observers. It became obvious to Chiang Kai-shek, the Chongqing municipal authorities, and Air Defense Command that while they could blame-at least before the war ended-the Yellow River flood of I938 on the Japanese (whom they accused of blasting the dikes), they had to admit to their failure to supervise the use of the Great Tunnel and to provide immediate relief to the victims in the face of negative press and widespread public condemnation in China. There was a limit to how much they could blame the Japanese for the Disaster.

Scholars have reached a consensus that modern China's disasters were partly a result of perpetual warfare waged first among Chinese warlords and then between China and Japan. Wars ravaged the national economy and there was no effectively centralized state in place to coordinate disaster prevention, management, and relief, which exacerbated the impact of a disaster when it struck. Nevertheless, the almost exclusive attention to famines and floods and their long-term impacts on environments, militaries, and societies across various provinces leads to unavoidable generalizations and lacks specific contexts. As disaster researchers and social scientists have ascertained, various empirical observations, theoretical leanings, and classificatory logic have pointed to considerable variation in what constitutes a disaster. Some proclaim that "there is no such thing as a natural disaster" in modern times, implying that human coordination, technologies, and will can mitigate or eliminate the effects of a disaster. ${ }^{34}$ In their view, the consequences of "natural" disasters are political

30 Janku 20I3, pp. 6-28.

3I For sample explanations of the rationale behind such decisions, see Lary 2004, pp. I6I-62, and Mitter 20I3, pp. $265-67$. As Schwarcz puts it, "to speak too much of grief is to blunt its edge" (I997), p. IIg.

33 On the relationship between disaster, nationalism, and newspapers, see Janku 20I 2, pp. 227-60 and EdgertonTarpley 20I4, pp. 447-69. 
and social in nature. Seen in this light, the Nationalist government and twentieth-century Chinese people's rejection of cosmological interpretations of disasters-long regarded in imperial China to have been sent by Heaven to punish a community for its lack of morality (and thus viewed as somehow human-induced)-suggested that government officials, in a somewhat modified version of the old social contract, were now expected to provide not only disaster relief but also preventive measures and resource management to keep casualties to a minimum. ${ }^{35}$ The Great Tunnel Disaster of Chongqing was a localized affair that occurred in a single city, and its consequences played out in a matter of weeks. Nevertheless, the concerns of disaster studies - the role of the state, foreign and public responses, and the politics of reportage-remain applicable, affording a glimpse into how the state and contemporary observers interpreted the Disaster.

\section{“CHUNGKING'S AIR-RAID TUNNELS: A MODEL FOR THE EAST"}

“Our main object in visiting Chungking," Wing Commander A. H. Steele-Perkins, Director of Air Precautions of British Hong Kong, said, "was to study the very excellent system they have devised for giving protection to the general public. It is protection of a very high order and almost bomb-proof." Steele-Perkins made this comment in January I94I. He estimated that there was sufficient tunnel accommodation for all 420,000 people in Chongqing. Large parts of those accommodations were furnished with electric light or Chinese spirit lamps. ${ }^{36}$

The Japanese war in China was the first conventional war in which air power as a weapon of shock and intimidation was applied in practice. 37 Japanese fighter planes bombed Manchuria in I93I, years before the bombing of Guernica in Spain (1937) and the Battle of Britain (I940). With the advent of full-blown war in 1937, the Nationalist government, which could produce no fighter planes of its own and feared Japan's superior air power, began its project of passive defense to construct public air-raid shelters in Chinese cities. ${ }^{8}$ With the Japanese occupation of Wuhan and the withdrawal of the Nationalist government to Chongqing in 1938, the Japanese high command determined that aerial attacks by Navy Air Force bombers conducted from Wuhan could damage Chongqing's economic and political structure, break the morale of the Chinese, and lead to Chiang Kai-shek's surrender. ${ }^{39}$ With excellent control and maneuverability, a top speed of more than 330 miles per hour at I5,000 feet, and a range of nearly 2,000 miles, the "Zero" fighter plane, introduced into China's skies in late I940, allowed the Japanese to gain absolute superiority in air combat in Chongqing; the Zero's predecessor, the navy's Type 96 carrier fighter, enjoyed an operational radius of only 375 miles, which could not cover the entire pp. 7 I -89 .

The figure of 420,000 was one of many rough estimates of Chongqing's wartime population. See “Chungking's Air Raid Tunnels: A Model for the East," The Sun, January 9, I94I. According to Wu Guozhen, then the mayor of Chongqing, the population was close to one million people by mid-I937. See Wu I995, p. 308. 
distance of 500 miles from the air bases in Wuhan to Chongqing. Because of the Zero, Japanese forces could intensify their bombing of Chongqing throughout I94I.40 In June alone, the Japanese launched fifteen airstrikes involving 494 aircraft against Chongqing. ${ }^{4}$

Chongqing is surrounded by canyons and tall mountains that made it safe from attack by Japanese ground forces. ${ }^{42}$ A commercial city in Sichuan, a province that served as both the political center of unoccupied China and the principal supplier of food, manpower, and provisions for Nationalist armies after the fall of Wuhan, Chongqing was often shrouded in a blanket of fog that limited Japan's summertime operations over the city from May to October. Sichuan was well connected to the overland supply routes (i.e., the Burma Road) used to bring in relief goods from Britain, the Soviet Union, and the United States, ensuring that Chongqing remained reasonably well provisioned throughout the War. ${ }^{43}$

Nevertheless, the Nationalist government also found itself having to rule a city and hinterland-rife with banditry, warlords, and the opium trade-that had never been brought completely under central control in the prewar years. The government set out to eliminate the political fragmentation that threatened its mobilization of the population and control over the scarce economic resources for the total war effort by attacking not only bandits and warlords_-of whom the hegemon was Liu Xiang 劉湘 (I888-1938)-but also the gentry's hold over local society. Self-professed wartime reformers among the elite refugees from the occupied coastal provinces (“downriver people” or xiajiangmin 下江民) facilitated the government's attempts to cultivate patriotic citizens and modernize rural regions by founding new institutions and leading social programs for conscription and tax purposes, which were ultimately unsuccessful because of the animosity between these reformersviewed by the natives of Sichuan as "Shanghai imperialists" and intrusive outsiders who aimed to levy the heavy burden of war on them-and the local powerbrokers determined to maintain their interests. ${ }^{44}$ The downriver people viewed themselves as representatives of "modernized" cities such as Shanghai and regarded the natives of Sichuan as a backward people of the isolated Chinese interior. 45 The residents of Chongqing were a "curious species of second-grade inhabitants." 46 It was not until the end of I94I that the Nationalist government circulated the Nationalist currency ( $f a b i$ 法幣) and instituted tax offices in the outlying areas of Chongqing. 47

Before his tactical retreat to Sichuan, which came to absorb the bulk of refugees from all over China, Chiang Kai-shek had established the Chongqing Air Defense Command in September 1937, charging it with responsibility for assisting and directing residents in

Hagiwara 20I I, pp. 246-49.

Guo 20I5, p. 9.

Maeda 2009, p. I40. See also Tow 20II, p. 258.

Kapp I973, p. I36; Maeda 2009, p. I40; Hagiwara 20II, p. 249. For an excellent analysis of the road freight transport in Chongqing, see Tan 2013, pp. 442-48.

Cook and Gilmartin 20I3, pp. I5I-27I. See also Kapp I973, pp. 62-86; 99-I20; I36-4I.

For more characteristics of the downriver people, see McIsaac 2000, p. I76, and Zurndorfer 20I3, p. 84.

White and Jacoby I946, p. 9.

Lin 2006, p. I20. 
digging and building simple anti-air-raid trenches. ${ }^{48}$ By February I940, Chongqing had 510 public air-raid shelters that could accommodate I62,580 people. ${ }^{49}$ Chiang instructed Chongqing’s Mayor Wu Guozhen 吳國楨 (K. C. Wu, I903-1984) and all of the city's municipal departments and task forces to provide the people with material support for building air-raid shelters..$^{\circ}$ The sanitation of the public shelters was poor, so Chiang ordered the municipal government to clean and disinfect them regularly and make "public living spaces" out of them for Chongqing's residents. The Nationalist and municipal governments, along with the people of Chongqing from all walks of life, acknowledged air-raid shelters as both a space for sociability and an integral part of their everyday lives. ${ }^{5}{ }^{\mathrm{I}}$

Chiang had direct experience with air raids in Nanjing and appeared genuinely dedicated to ensuring the safety and wellbeing of the Chinese people. He and his wife, usually in the company of prominent Nationalist officials and foreign dignitaries, attended public events and rallies that celebrated China's aerial engagement with the Japanese and the successful air-raid drills. Chiang was hoping to assure Chinese civilians that the Nationalist regime enjoyed the support of Western allies and remained devoted to the cause of resisting the Japanese..$^{2} \mathrm{He}$ and his wife also inspected the sites of intense Japanese bombing, shouting words of comfort and rendering medical assistance to injured residents. 53 They placed their private cars at the disposal of the Evacuation Committee, which commandeered all available conveyances and vehicles, both private and public, to transport people to shelters or the countryside prior to an air raid. 54

Providing adequate defense against aerial bombardments was a global issue in the first half of the twentieth century; China was not alone in this task. Shortly after World War I (I9I4-I9I8), a fear of aerial attacks (and the civilian breakdown and widespread destruction that they could cause) prompted the British Home Office to plan national air raid precautions (ARP), which involved anti-gas preparations, the construction of brick shelters, and evacuation procedures. Images of the helpless victims of Guernica, where aerial bombardments claimed an estimated I,650 lives, strengthened the Home Office's resolve to build deep underground shelters and not rely on cellars and converted basements (which had failed in Spain) for civilian protection. 55 The British people were deeply afraid of bombing because of widespread media coverage of the bombings in Spain, prompting the Home Office to prepare emergency services such as firefighting, medical aid, and assistance for people made homeless by bombing. ${ }^{6}$

48 Chang 20II, p. 65

49 Ding 20I2, p. I9. The continuous refugee flow into Chongqing rendered any population census speculative. Another estimate suggests that in I940 (month unknown), Chongqing built I,865 public air-raid shelters to accommodate 444,988 people. See Xu 200I, p. I3I.

Cheng I993, pp. 92-94. 
With the popular memory of the Guernica attacks vivid, the Japanese aerial bombings of Guangxi, Guangzhou, Hankou, and Nanchang in I 938 received concerted press coverage in Britain.57 The British government compared the Chinese to the Spaniards and determined that the Chinese were more efficient and prepared (this perception was perhaps remarkable, given that British opinion was more attentive to Spain, which was geographically nearer and politically more relevant)..$^{8}$ In China, whole armies were saved when they left their barracks and took cover in the surrounding countryside in anticipation of a raid, and inland cities had approximately twenty minutes of warning and reaction time. In contrast, Spanish coastal towns were given extremely short notice.59 Even Theodore H. White, who was critical of Chiang Kai-shek, opined that Chongqing's warning system was a "monumental elaboration of Chinese ingenuity"; two-man teams watched the skies for enemy planes and relayed news of an impending raid to Chongqing via radio; paper lanterns, hung on poles atop Chongqing's tallest hills, complemented the siren system to inform residents to run for cover. ${ }^{60}$ The American press's opinion of Chongqing's air defense capabilities confirmed these observations. A journalist wrote that Chongqing, with its underground shelters and perpetually foggy weather, was "one of the most nearly bombproof cities in the world." 1 I A report in I940 even claimed that in Chongqing, "casualties in future air raids should be virtually nil although there is always some property damage to be expected." ${ }^{2}$

To foreign observers, Chongqing seemed like an impregnable fortress, defended from air strikes by mountainous terrain and supported by an extensive network of air-raid shelters and anti-air-raid trenches. However, several lurking flaws threatened the functionality of the public air-raid shelters. For one thing, although the capacity of each public air-raid shelter was approximately 300 people, the shelters were constructed in locations that were not planned according to population density. As a result, in some densely populated areas, a shelter might have to accommodate thousands of people during a single air raid. The air-raid officers and wardens who formed the Protection Group were responsible for maintaining the public shelter facilities in peacetime and guarding the shelter entrances during air strikes, but they were easily bribed by city dwellers desperate to enter the shelters. The officers and wardens were also notorious for being negligent in the performance of their duties, and some would run for cover during an air raid instead of guiding people into the shelters. In addition to the human factor, the engineering of the public air-raid shelters was also flawed. Although an ideal air-raid shelter, according to Chongqing municipal records, should possess two entrances (each two meters in breadth and six meters in depth) that would converge into an underground tunnel, a lack of funds meant that

57 Grayzel 20I2, p. I92.

58 Buchanan 20I2, pp. 533-52.

Ibid. I94. See also Meisel I994, pp. 300-319.

60 The lanterns were lit at night: two red ones meant that the enemy was coming close with bombs and fireballs, a long green paper stocking was the all-clear signal, and a black lantern warned of gas bombs (White and Jacoby I946, pp. I3-I4). Owen Lattimore (I990, p. I2I) regards the Chinese air-raid alarm system as "marvelously efficient."

6I "New tunnels and fog make Chungking safe," New York Herald Tribune, February 26, I939.

62 "China's war capital expands despite raids," The Christian Science Monitor, January I3, I940. 
these requirements were frequently disregarded in the construction of public air-raid shelters, which were shallower or smaller than what was stipulated in the proposed template. ${ }^{63}$

The Great Tunnel had three entrances of more than ten meters in depth. It was 438.4 meters broad and 2.5 kilometers long, with a maximum capacity of 6,500 people. Nevertheless, it was similarly under-equipped, lacking thick walls, benches, drains, kerosene oil lamps, propeller fans, communication equipment, and pillars. More importantly, the Great Tunnel suffered from a fatal deficiency: it was too deep and lacked ventilation holes large enough to provide a constant supply of oxygen during a prolonged air strike. To complicate matters, the Great Tunnel was located in one of Chongqing's most densely populated commercial and residential wards: the "Eighteen Stairs" (shiba ti 十八梯). The lack of propeller fans to ventilate the tunnel, as we shall see, would have dire consequences for the people sheltered in it. ${ }^{64}$

Although Chongqing's civil defense preparations gradually became more efficient in the eyes of both Chinese and foreigners, the system's effectiveness continued to rely on human judgment and execution. ${ }^{65}$ The system was subjected to an entirely new test in the spring of I94I when the latest Japanese fighter planes, which could fly unusually low and fast, swept over Chongqing and quite literally machine-gunned the streets after the bombers had dropped their explosives. Additional tunnels constructed in previous months had increased the capacity of bomb-proof shelters to more than 300,000 people, but the teeming population of refugees meant that Chongqing never had enough shelters. ${ }^{66}$

The poor quality of the air-raid shelters, compounded by their lack of evacuation plans and dire shortages of food, supplies, and equipment, fostered a prevalent perception in Chongqing of the Nationalist government as corrupt, incompetent, and negligent. The government's failure to confiscate private air-raid shelters - those of high officials and wealthy businessmen-even in times of crisis to fill the shortage of public shelters further fueled public indignation. ${ }^{67}$ However, these endemic problems had not sparked a public outcry because the Nationalist government's total war mobilization had galvanized and politicized both elites and ordinary people. The fortitude and sacrifice of Chongqing's residents translated into the nation's service: citizens endured both inconveniences and life-threatening situations with the implicit understanding that in principle, everyone in China was experiencing the same suffering. In return, ordinary Chinese expected equitable treatment from the nation that they were defending in the extreme circumstances of technological warfare. ${ }^{68}$ This contract would be breached if the people were to determine that the authorities had failed in their responsibilities to provide public shelters to protect them from enemy bombers and planes. The Nationalist government did attempt to provide air-raid

63 Ding 2012, pp. I8-30.

64 For the dimensions of the Great Tunnel, see Chongqing shi renmin fangkong bangongshi, ed. I994, p. 437. See also Chongqing kangzhan congshu bianzhuan weiyuanhui, ed. I995, pp. 53-54.

65 Tow 20II, p. 274.

66 The capacity of 300,000 people included both public and private air-raid shelters. See "Chungking raiding renewed by Japan," The New York Times, March I9, I94I.

67 Luo 2009, pp. I9I-92.

68 Gardiner 20II, pp. I8I-82. 
shelters on a mass and equitable basis, and both official and unofficial reports indicated that by June I94I, as many as 500,000 Chongqing residents had access to public shelters in the event of an air raid. ${ }^{69}$

Nevertheless, a harsh critic of the Nationalist government, the celebrated writer Han Suyin, wrote of the public air-raid shelters:

The shelters were scooped-out tunnels in the rock, and because Chungking was all rock, with protrusions and small hollows and hillocks almost everywhere, the bowels of these promontories could easily be utilized. However, some of the common shelters had been dug in softer earth and were unsafe. They caved in after a while. There was no ventilation in them, and the people who sat deep inside, away from the one and only outlet, the mouth of the tunnel, became anoxic if the raid was prolonged. They started to thrash about, or to faint. In between the explosions, there was respite. While anticipating the next batch of bombs, anyone could come out of the dugout, sit around the mouth of the cave, fan, and gulp the hot air. However, there was hardly any shade, and if there was a single bush, it was monopolized in its thin narrow coolness by some police squad or some self-important official and his family. The heat pounded upon the rock, the day wore on and on, the hours were a casque of hot lead, were sweat, were suffocation and thirst; a single large wooden bucket was provided for the men to relieve themselves at the mouth of the shelter; nothing was provided for the women. The children could squat about, and the area became noisome with smell and flies. ${ }^{70}$

Because of the appalling conditions of most public air-raid shelters, most of Chongqing's people were unwilling to enter them unless they had absolutely no choice. ${ }^{\text {I }}$ Despite being hailed as having the "finest passive air defenses in the world" by American and British standards, Chongqing was ill-prepared for the unusually long night of bombing on June 5, 194I. $7^{72}$

\section{A NIGHT TO REMEMBER}

At approximately 6 p.m. on June 5, I94I, Guo Weibo, a trainee at the Nationalist Government Military Committee Personnel School, was finishing his dinner when he heard the air-raid sirens. He and approximately sixty of his classmates dashed out and entered the Great Tunnel via an entrance near a cinema. Although they could have entered a sturdier air-raid shelter at the Chongqing Garrison Command Inspection Department, the animosity between their School and the Department ruled out entering that shelter, so they were forced to enter a public air-raid shelter instead.

69 Howard 2004, p. I28.

Han I968, p. I82.

Chang 20II, p. 68. 
It had been a long time since the Japanese planes had last come, and even longer since an air raid under cover of night. Caught by surprise, residents clamored for entry to the Great Tunnel. In the tunnel, which had a capacity of approximately 4,000 to 5,000 people, more than I0,000 people jostled one another for air and physical space. At approximately 7 p.m., Guo heard the emergency siren, the signal for the tunnel gates to close. Guo sat with two of his classmates on a bench near one of the gates; they refused to move deeper into the tunnel "because they were Cantonese."73

At approximately 9 p.m., Japanese planes continued with their bombardment, and Guo could hear the thunderous explosions and sense the seismic vibrations. It was during this time that the people in the tunnel began to swelter and feel breathless. The kerosene lamps dimmed-a sure sign of a lack of oxygen. The temperature rose and with the slow but certain depletion of oxygen, the threat of death loomed ever closer. An uncanny silence filled the tunnel. No one wanted to make the first move, but everyone was intently observing their surroundings while enduring their discomfort. As the situation deteriorated, the wails of babies and children became increasingly intense. The lamps went out, which was a signal for everyone to rush out of the tunnel. Carried along by the flow of the crowd, Guo and his friends reached the gate with relative ease. Unfortunately, the gate could only be opened from the outside. ${ }^{74}$ Screams, moans, and cries filled the tunnel. For some reason, the wooden gate finally opened, but members of the Protection Group were nowhere in sight. Like a river gushing out of a broken dam, torrents of refugees poured out of the tunnel. Guo and his friends were strong enough to withstand the impact of people being forced out of the tunnel. Fending off giddiness, they climbed up the stairs and emerged onto the ground. 75

Many others were not so fortunate. Guo could hear blood-curdling shrieks coming from the tunnel thirty meters from the opening. For a long time, Guo observed that not a single person had emerged from the tunnel amid the screams. A mixture of heat and stench assailed him and his classmates as they attempted to re-enter the tunnel to rescue their classmates. Guo observed twenty to thirty corpses blocking the path that led into the deeper parts of the tunnel; dozens of corpses, the result of a stampede, were piled at the foot of the ladder that Guo had used to escape from the tunnel. A stream of people had gathered behind the pile of bodies. Although the opening was blocked, the people inside the tunnel continued to push against those in front of them. When Guo found his classmates who were trapped in the tunnel, their faces were red and swollen, and they ripped their own clothes in agony. Soon it was I2 a.m., then I a.m., and then 2 a.m., but no rescue team

"Cantonese"-Guangdong Province was a modernized part of China-might have been a generic term for members of the police squad or the Nationalist army. They belonged to the category of downriver people.

74 The air-raid shelters in Chongqing were designed to reduce confusion and leave all decisions to open or close the entrance gates solely to Air Defense Command, whose officers acted based on the descriptions of the shelter wardens. One reason for this design was that poison gas could be delivered from the air, as had occurred during the Italian attack on Abyssinian civilians in 1936; only people on the outside of the shelter knew when it would be safe to open the gate for evacuation. See Meisel I994, p. 304. Deputy Air Commander $\mathrm{Hu}$ Bohan allegedly ordered the wardens not to open the gate because he feared that any action might lead to chaos in the Great Tunnel. See Liu 2010, p. 47.

75 The Great Tunnel had eighteen flights of stairs, which were ladders leading up to the surface. See Ding 20I2, p. 30. 
arrived. It was not until daybreak that the air-raid sirens stopped and government officers came not to rescue the people but to clear the bodies in the tunnel. ${ }^{6}$ Countless refugees had been crushed, suffocated, or trampled to death, and the thousands of corpses of people who died in the stampede had to be transported in trucks to a clearing area for mass burial. ${ }^{77}$

\section{A STAMPEDE OF NARRATIVES}

The Great Tunnel Disaster of Chongqing generated widespread concern and discussion among the Chinese public. Chinese estimates of the death toll vary widely, ranging from 992 to I 2,000. ${ }^{78}$ The Nationalist state's inequitable allocation of shelter space and apparent disregard for civilian safety was placed under intense public scrutiny. ${ }^{79}$ The editorial and forum pages of magazines and newspapers were inundated with criticisms of the Nationalist government, citing that this was not the first time that poor ventilation had resulted in the suffocation and death of people seeking refuge in a public air-raid shelter. An editorial wrote as follows:

I regret to know that the officers in charge had not been able to prevent this disaster! This is not a new problem: on II June of the preceding year, there was suffocation in the great tunnel under Zhongshan Park; on I2 August last year, another case occurred in the great tunnel under Zuoying Street ... our newspaper had published a commentary on the ventilation problem in public air-raid shelters ... [The problem is entirely caused by] unsatisfactory equipment and improper management! ${ }^{80}$

One forum article also mentioned that the high death toll of the most recent disaster was the result of the small size of the tunnel's ventilation holes and poor ventilation generally, compounded by mismanagement on the part of the relevant personnel. ${ }^{81}$ Chiang Kaishek's confidant, Tang Zong 唐縱 (I905-I98I), observed that Chiang was visibly distressed by the Disaster.82 On June 8, I94I, Chiang relieved Wu Guozhen, Air Defense Commander Liu Zhi 劉峙 (Liu Chih, I892-I97I), and Deputy Air Commander Hu Bohan 胡伯翰 (I900-

76 Guo I992, pp. I72-79. I have translated Guo's account because it is the most detailed and representative. Other accounts are largely similar in chronology and experience. For more accounts, see Zhou, ed., 20IIa, pp. 337-77. For an overview of the Disaster, see Xie, ed., 2005, pp. 75-95.

Zhongguo renmin zhengzhi xieshang huiyi Sichuan sheng Chongqing shi weiyuanhui, ed. I985, pp. I89-90.

The highest estimate of I 2,00o, although incredible, gained some credence in Mainland China. For more estimates of the death toll, which remain inconclusive, see Pan 20I3, pp. I2-I3. We do not know whether more people died in the Great Tunnel than in the rest of Chongqing combined during this air raid on June 5, I94I.

Chang 20II, p. 69.

80 “Wenti zai shebei buzhou guanli qiantuo 問題在設備不周管理欠妥” (“The problem lies in unsatisfactory equipment and improper management”), Shilun fenxi 35 (I94I), p. 22. To be sure, those earlier instances suffered lower casualty rates and received far less press coverage than the Disaster.

8I “Fangkongdong tongfeng wenti: shiping 防空洞通風問題: 時評” “"The problem of ventilation in air-raid shelters: a commentary"), Ta Kung Pao, June 7, I94I.

82 Gong'anbu dang'anguan, ed., I99I, p. 2 I3. 
I973) from their posts, but he ordered them to carry on with their duties until further notice. ${ }^{83}$ However, appeals for stronger action against the trio and other personnel involved continued:

[On the issue of responsibility,] the government has set up a seven-member committee to investigate, and before long, we would know who ought to be responsible [for the Disaster]. Besides dismissing Liu Zhi, Hu Bohan, and Wu Guozhen, there will surely be more appropriate punishments [after the investigation is completed] to appease the city residents ... we should not concentrate our anger on members of the Protection Group because they are all low-ranking officials whose knowledge is deficient. These low-ranking personnel have no say over the poor conditions of the shelters, and their blind obedience resulted in inflexible execution of their duties ... high-ranking officials, for their poor leadership of their subordinates, should bear far greater responsibility for the disaster. ${ }^{84}$

Several readers demanded more severe penalties for those held responsible, who, in their eyes, were not restricted to $\mathrm{Wu}$, Liu, and $\mathrm{Hu}$. They deemed Chiang's treatment of the responsibility issue to be perfunctory and symbolic, not concrete and serious. While "praising" Chiang for his "magnanimity" and "restraint," these readers wanted the "relevant authorities" to assume complete responsibility and answer for their callous disregard for human life. Invoking the term zuzhi 組織 (“organization”), some contributors refrained from finger-pointing while expressing their resentment of the culprits in the zuzhi. They urged their leaders to be decisive in meting out necessary punishments to answer to the people. $^{85}$

More specifically, the Communist paper Xinhua ribao 新華日報 (Xinhua Daily) carried reports on the lack of accountability and transparency in the investigation and treatment of the aftermath of the Disaster. An editorial in Xinhua ribao wrote that despite appeals from and speculations by the public, there had not been one word about the culpability of the Air Defense Command. While reaffirming the widespread opinion that the punishments of $\mathrm{Wu}$, $\mathrm{Liu}$, and $\mathrm{Hu}$ were too light, the editorial also noted that the opportunists who robbed the dying and dead of their valuables also ought to be apprehended and punished. ${ }^{86}$

An article in Xiandai gonglun yuekan 現代公論月刊 (Public Opinion Monthly) identified the opportunists as members of the medical and rescue teams who had been dispatched to the site of the Disaster. The opportunists, who were police officers and members of

83 "Dismissals in Chungking," The New York Times, June 8, I94I; "Wei suidao zhixi can'an Jiang weiyuanzhang shouling checha Liu Zhi Hu Bohan Wu Guozhen wanhu zhiwu gezhi liuren 為隧道窒息慘案蔣委員長手令 徹查劉峙胡伯翰吳國楨玩忽職務革職留任 ” ““Chairman Jiang orders investigation of tunnel suffocation disaster: Liu Zhi, Hu Bohan, Wu Guozhen dismissed for neglect of duties but remained in office”), Xinhua ribao, June 8, I94I.

84 “Jigou pangza guanli buliang 機構龐雜管理不良” (“Complex organization and poor management”), Shilun fenxi 35 (I94I), p. 23.

85 “Ru bu yanban shouyao wu yi dui guoren 如不嚴辦首要無以對國人” “"If there is no severe punishment, there is no answer to the people"), Shilun fenxi 35 (I94I), pp. 23-24.

86 “Suidao can'an shanhou wenti: shiping 隧道慘案善後問題: 時評” (“The problem of the aftermath of the tunnel disaster: a commentary"), Xinhua ribao, June Io, I94I. 
the Protection Group, stripped bodies and casualties of cash and valuables instead of attending to them (most refugees ran into air-raid shelters carrying their most precious items, fearing their homes would be bombed). ${ }^{87}$ The article reported that the high death toll and the misconduct of prominent officials in the Disaster were inconvenient truths that tarnished the credibility and reputation of the Nationalist government. Xinhua ribao asked the government to do the following: I) publicize, verify, and return the belongings of the dead to surviving family members; 2) construct a memorial to commemorate the dead; 3) provide the families of the dead with pensions and privileges; and 4) strengthen the management of air-raid shelters to prevent a recurrence of the Disaster. ${ }^{88}$ In the following weeks, Xinhua ribao continued to publish extensive reports, essays, and poems on the Disaster. ${ }^{89}$

Mounting distrust and tension between the Nationalist government and the Chinese public over the handling (or mishandling) of the aftermath of the Disaster was exacerbated by the rumors that eroded the integrity of the Nationalists. A reader of Dazhong shenghuo 大衆生活 (Public Life) suggested that the Disaster was a premeditated plot by Nationalist agents (tewu 特務) to eliminate political opponents and the "promising young" (youwei qingnian 有為青年)—the people who had been resisting the government's authoritarian rule-by "welcoming" them into the Great Tunnel and killing them there. An "objective" reader wrote in to refute this, stating that the Nationalists were not short on methods to eradicate their enemies, so they had little need to carry out a mass slaughter that would involve so many innocent people. ${ }^{\circ}$ These were sardonic political commentaries, which everyone knew; irony and sarcasm abounded in wartime Chongqing. Nevertheless, they reflected a significant segment of the Chinese public that was disillusioned with the government's failure to punish the alleged perpetrators.

Another reason for the public's overall frustration with the Nationalists was the conspicuous lack of high-ranking officials and social dignitaries among the casualties. Almost all of the dead were factory workers, laborers, small merchants, soldiers, students, and teachers. ${ }^{91}$ Of the dead, 60 percent were women and 12 percent were children. ${ }^{92}$ It was later revealed to the public that government buildings and private companies possessed their own air-raid shelters that were better equipped and had large capacities. The bestbuilt air-raid shelters, according to public opinion at the time, were the ones owned by the head offices of the Bank of Communications, the Agricultural Bank, and the Sichuan Salt Industry Bank. ${ }^{93}$ Coolies and ordinary residents had to content themselves with the deplorable public air-raid shelters. ${ }^{94}$ Skeptics painted a picture of negligent government

87 Xiandai gonglun yuekan 7:4 (I94I), p. 2I.

88 "Haowai” (“Exclusive”), Xinhua ribao, June 7, I94I.

89 Liu 2010, pp. I6-I7.

90 “Guanyu Chongqing suidao zhixi’an 關於重慶隧道窒息案” (“Regarding the case of the Chongqing tunnel suffocation"), Dazhong shenghuo Io (I94I), p. 250.

9I Chang 20II, p. 69. See also Lattimore I990, p. I2I.

92 Wu I995, pp. 332-33.

93 Chang 20II, p. 63.

94 “Da fangkongdong zhi canju 大防空洞之慘劇” (“The disaster of the Great Tunnel”), Xiandai gonglun yuekan 7:4 (I94I), p. 20. 
officials who "smoked cigarettes and drank soda" in their well-provisioned shelters and ignorant, indifferent low-ranking officers who, "oblivious to the chaos in the Great Tunnel, ordered the refugees not to leave and locked the gate to the tunnel," sealing the evacuees' fate. 95 A prevalent rumor had also spread that the assistance teams dispatched to the site had been encouraged by their superiors to rob the victims of valuables and share the loot. ${ }^{96}$

The owners of private shelters - the major banks and companies-were also known to have laid telephone cables to Air Defense Command and bribed government officials to provide them with the latest information on impending air raids. Because the operators of telephone lines to the rich and powerful had been fed bribes, whereas those who manned the lines to the public air-raid shelters had little to gain from the common folk, ordinary residents from the middle and lower classes were always among the last to realize when an air-raid warning was lifted, resulting in the high number of casualties suffered in the Disaster. The public siren that functioned to announce the end of an air raid usually sounded long after the last planes had departed. To be fair, however, the Japanese bombing raids came in waves, and Air Defense Command often did not dare lift the warning until it was certain that the raid was over.97 Guo's testimony revealed almost all the failures of the government's air-raid defenses. The continuous influx of refugees into Chongqing ensured that the city's population would constantly outnumber the available air-raid shelter spaces (it is worth recalling at this point that Guo was from Guangdong Province and had been drafted into the Nationalist army). ${ }^{8}$ Nepotism and politics differentiated the haves from the have-nots. There was inadequate provision of air-raid defense facilities for ordinary people and the defense personnel had insufficient training. What really mattered in this "stampede of narratives" was not what had happened; the main point was that narratives arose to challenge the legitimacy of the Nationalists as the people's guardian against the Japanese.

Indeed, the Nationalists' embarrassment in the aftermath of the Disaster reached such a pitch that concerned supporters of the government, who were angry at the officials for their inability to redress the victims' grievances, were angrier still over the fact that officials had done little to salvage their flagging reputation. The chief editor of Ta Kung Pao, Zhang Jiluan 張季鸞 (I888-I94I), was a longtime supporter of Chiang Kai-shek. Although he was gravely ill at the time of the Disaster, he believed it was imperative to meet Chiang and make him understand how furious the public was about the Disaster, which he defined as the most serious catastrophe since the 1938 Changsha Fire. ${ }^{99}$ Realizing the gravity of the situation, the Nationalists quickly launched a media campaign that emphasized both the inevitability of war and the competent handling of the Disaster's aftermath by government officials. Tianjia banyuebao 田家半月報 (The Christian Farmer), a pro-Nationalist 
magazine that aimed to educate the peasantry, argued that the Disaster's high death toll was the result of unfinished construction work. Previous air raids, according to its editorial, resulted in few casualties, and it was only the combination of a prolonged night raid, persistent enemy strikes, and the unfinished construction of the Great Tunnel that had resulted in the Disaster. Indeed, Chiang Kai-shek was so incensed that he "immediately dismissed Liu Zhi, Hu Bohan, and Wu Guozhen from office" and personally appointed a committee to investigate why the Disaster had happened. The report concluded that Chiang was genuinely concerned about the people. ${ }^{\text {Ioo }}$

Another editorial in the same newspaper wrote that the government had furnished all public air-raid shelters with lamps, telephones, and ventilation pipes; additionally, it had allocated a sufficient number of men to manage the shelters and guide the refugees into them in the event of an air raid. For the families of the Disaster's dead, the government offered monetary compensation and allocated special funds to assist helpless widows and children. The government also had programs to help people who were above the age of sixty and people who were younger than twelve and, to people "who are still economically productive," the government gave some seed money to help them make a living. ${ }^{\text {IоI }}$ The old, weak, and disabled each received a payout of 300 yuan, whereas children orphaned by the Disaster received 200 yuan. By September I94I, the government had distributed I I0,000 yuan to the Disaster's survivors and victims. ${ }^{\text {I02 }}$ It was also highly publicized that major commercial banks had made huge donations to the government for the construction of new air-raid shelters in the densely populated areas of Chongqing. ${ }^{\text {I03 }}$ The government was attempting to restore its credibility in the face of harsh criticism.

The American (and British) media, largely sympathetic to the Chinese effort to keep China in the war against the Japanese, leapt to the Nationalists' defense. ${ }^{\text {Io4 }}$ The New York Times, citing a Chinese official, explained that the Disaster had occurred because it was the first night raid in a long time and the ventilation system was out of order, noting that Chiang Kai-shek had called for a conference to discuss the prevention of similar disasters in the future. ${ }^{105}$ The American newspaper also reported that rescue squads had

Ioo “Chongqing dasuidao mensi renmin shubai weizuo heran danu 重慶大隧道悶死人民數百委座赫然大怒” ("Chongqing Great Tunnel suffocated hundreds of people: Chairman is furious"), Tianjia banyuebao I 2:8 (I94I), p. 3 .

IOI “Chongqing dasuidao can’an jiejue le 重慶大隧道慘案解決了” (“The Chongqing Great Tunnel Disaster: solved”), Tianxia banyuebao I5/16:8 (I94I), pp. 4-5. See also Chongqing shi renmin fangkong bangongshi, ed., I994, pp. 432-33. Similar reports appeared in Ta Kung Pao and Zhongyang ribao, July 24, I94I.

I02 “Jingdao Zhang Jiluan xiansheng 敬悼張季鸞先生” (“Condolences for Zhang Jiluan”), Zhongyang ribao, September 7, I94I.

I03 “Chongqing dasuidao zhixi’an jiyao 重慶大隧道窒息案紀要” ““A summary of the Chongqing Great Tunnel suffocation”), Guoji laogong tongxun 7/8 (I94I), p. I5I. See also "Gaijin Chongqing suidao sheshi fenyou fangkong silingbu, shizhengfu jiagong ganzhuang 改進重慶隧道設施分由防空司令部市政府加工改裝” ("Improvements on Chongqing tunnel facilities by Air Defense Command and Municipal Government"), Zhongyang ribao, June I5, I94I.

I04 The Americans provided the Nationalist government with five million US dollars to improve its air defense. See “Dui peidu kongfang wanshan beizhi zanyang: wubaiwan meijin juankuan jinxing shunli 對陪都空防完 善備至讚揚: 五百萬美金捐款進行順利” ““Chongqing”s excellent air defense praised: five million US dollars donation in smooth progress”), Shenbao, June 7, I94I.

I05 "700 Chinese killed in air-raid shelter," The New York Times, June 7, I94I. 
worked around the clock to remove the bodies of those killed in the Disaster. ${ }^{\text {I06 }}$ The Nationalist government co-opted the horrors of the Disaster to inform Western audiences about their resolve to resist Japan. The Nationalists produced feature films that showed Japanese bombers flying in vast formations over China and portrayed the havoc they wrought. As the government attempted to stress in these films, China had "plenty of soldiers, a vast terrain to exhaust Japan, and a powerful will to fight back," and its greatest hope was "America's promise to supply her with the arms to wage that fight." ${ }^{\circ}$ 7 The celebrated writer Ernest Hemingway, who was in China at the time, agreed with the American Ambassador to Chongqing, Nelson Johnson, that "China can do anything that China wants to do," bringing to Japan the "horror that she has spread through China in the last four

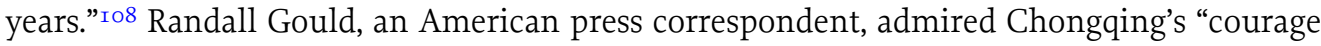
under bombing” and Chiang Kai-shek's "calm confidence." ${ }^{\circ o 9}$ Foreigners in Chongqing appealed to the American government not to sell gasoline to the Japanese. ${ }^{\text {I }}$

The responses of the Chinese public to Chongqing's Great Tunnel Disaster at the time revealed that unlike what the prevailing reenacted accounts of the Great Bombing of Chongqing would like us to believe, the Nationalist government, not the Japanese, was criticized in the immediate aftermath. Critics of the government pointed to its culpability in the high death toll - a direct consequence of its corruption and incompetence-and made no mention of the Japanese or their air strikes. The government attempted to downplay their allegations by defining the Disaster as an outcome of Japan's war of aggression against China. Although the government's foreign propaganda efforts were successful in receiving vocal support from the West (which, unlike in the aftermath of previous famines and floods, did not condemn the Nationalists for being callous), the officials failed to divert domestic attention away from their inability to prevent or reduce disaster loss in the Great Tunnel.

\section{THE VERDICT}

What is the most fundamental principle [of politics]? It is the principle of linking the government with the people to go through life and death together ... the people should obey the government and sacrifice all they have to realize the objective of resisting the enemy ... office holders must dedicate themselves to fulfilling their duties ... The Great Tunnel Disaster is the most unfortunate and disgraceful event that has happened in the past four years of resistance. Understanding that our nation is weak and that we lack experienced and talented men, we can forgive many things. However, when there are so many ways to prevent this Disaster from happening and save the victims, many lives are lost! I think we must find out who is responsible for this!

\footnotetext{
I06 "6o planes attacked Chungking center," The New York Times, June 8, I94I.

I07 "Film reveals China's efforts for victory," The Washington Post, June I2, I94I; "China makes films under rain of bombs," The Washington Post, July 29, I94I.

I08 "US envoy says 'China can do anything China wants to do'," The Washington Post, June I7, I94I.

Io9 Gould I946, p. I84.

I Io “Japanese bombers responsible for ‘black hole’ of Chungking," The China Weekly Review, June 28, I94I.
} 
Otherwise, law and order will lose their dignity, and [if this is so,] on what basis can China achieve its final victory?! We firmly believe that the seven-member Review Committee can perform its duty diligently, live up to their leader's expectations and trust, and fulfill the people's hopes [for justice]. ${ }^{\text {II }}$

Despite the efforts of the Nationalist government and its Western allies to assuage the Chinese people's anger and grief over the Disaster, calls for a fair and thorough investigation and trial of the alleged perpetrators never subsided. To many people, including the contributor who penned the above article, the Disaster was "most unfortunate and disgraceful" because it was the result of domestic mismanagement and oversight, not the result of a battle with a military opponent. To restore public confidence, Chiang Kaishek acted on Wu Guozhen's advice and formed a review committee to appease the Chinese people, emulating the Western practice of setting up a court of inquiry in the event of a disaster. Chiang also transferred responsibility for building and managing Chongqing's air-raid facilities and shelters from Air Defense Command under Liu Zhi to the municipal authorities under Wu Guozhen. ${ }^{\text {II } 2}$

Chiang Kai-shek called his committee a "Review Committee" because it served two purposes: I) to investigate the reasons for the Disaster; and 2) to conduct research on improving the equipment and facilities of public air-raid shelters. ${ }^{113}$ Zhongyang ribao 中央日報 (Central Daily News) was the mouthpiece of the Nationalist government, but when the review was in progress, it published several commentaries and editorials that attributed the high death toll to government officials' lack of responsibility (that said, Zhongyang ribao provided the lowest estimate of the death toll and casualties, at 46I and 29I respectively). ${ }^{\text {I } 4}$

Other reports bolstered this claim, and Air Defense Commander Liu Zhi became particularly notorious for his venality. As a high-ranking general, Liu Zhi established many redundant committees and departments within Air Defense Command and received government funding for every organization that he headed. ${ }^{\text {I5 }}$ In his memoirs, Wu Guozhen claimed that in every air raid, he and $\mathrm{Hu}$ Bohan would report to the Air Defense Command center, but Liu Zhi was never there. ${ }^{\text {II } 6}$ The overlap of jurisdiction and job scope resulted in administrative inefficiency and at the time, people talked about how officials had been appropriating funds meant for the construction of public air-raid shelters, leading to the construction of sub-standard air-raid shelters that did not

\footnotetext{
I I “Chedi yanshen zhengsu gangji 徹底嚴審整肅綱紀” (“Investigate thoroughly and boost discipline”), Shilun fenxi 35 (I94I), p. 25.

II $2 \mathrm{Wu}$ I995, pp. 333-35.

I 3 "Jiang weiyuanzhang feichang guannian mou suidao shijian, te ming zu fancha weiyuanhui, chedi chajiu yi ming zhenxiang 蔣委員長非常關念某隧道事件, 特命組翻查委員會, 徹底查究以明真相” “CChairman Jiang is gravely concerned about the tunnel case: special organization of Review Committee to investigate thoroughly and seek the truth"), Zhongyang ribao, June 9, I94I.
}

II4 Zhongyang ribao, June 6, I94I; June II, I94I; June I2, I94I; June I3, I94I; and June I5, I94I.

II5 For a full list of Liu Zhi’s official appointments, see Liu I966, pp. I5I-55.

II6 $\mathrm{Wu}$ i995, p. 3I3. 
meet safety requirements. ${ }^{\text {II }}$ The public was also aware of and upset by the government's nepotism: Wu Guobing 吳國柄 (I900-I987), Wu Guozhen's elder brother, constructed almost all of Chongqing's public air-raid shelters for the municipal authorities even though he was unfamiliar with engineering. ${ }^{18} 8 \mathrm{Wu}$ Guozhen confirmed the opinion at that time in his memoirs. He revealed both that Hu Bohan had invited quotations to outsource shelter building and that Wu Guobing knew the lowest quote and could therefore outbid his competitors to receive the contract. ${ }^{\text {II } 9}$

On June I8, I94I, the case was brought to the Chongqing District Court. That same day, the Nationalist government announced that all of Chongqing's public air-raid shelters had been well furnished with electric fans, lamps, and telephones and could accommodate more than 370,000 people. ${ }^{120}$ On July 2, I94I, the much-anticipated Dasuidao zhixi an shencha baogao 大隧道窒息案審查報告 (Great Tunnel Suffocation Case Review Report) was released to the press. Divided into two main sections, "Fact” and "Case Analysis," the Report ascertained that 992 people had died in the Disaster and I I 5 people had been injured. The Report noted the following: I) the construction and design of the gates and the ventilation structure of the Great Tunnel were flawed; 2) Air Defense Command had failed to install, before the deadline stipulated by the relevant bodies, the ventilators in the tunnel; 3) the maximum capacity of 4,384 was exceeded, which, coupled with the absence of ventilators, resulted in the victims' suffocation; and 4) the main causes of the Disaster were the Great Tunnel's defective design, blatant mismanagement, and dreadful leadership. ${ }^{\text {I I I }}$

Upon the release of the Report, Chiang Kai-shek permanently dismissed Liu Zhi-largely regarded at the time to be the main culprit-and appointed He Guoguang 賀國光 (I885-I969) to replace him as the new Air Defense Commander. ${ }^{\mathrm{I} 22}$ The municipal authorities also took over from Air Defense Command in building and maintaining air-raid

II7 “Wenti zai shebei buzhou guanli qianque 問題在設備不周管理欠缺,” Shilun fenxi 35 (I94I), p. 23. See also Pan 20I3, pp. 280-8I, and Zhongguo renmin zhengzhi xieshang huiyi Sichuan sheng Chongqing shi weiyuanhui, ed., I983, p. 97.

II 8 On how and why Wu Guobing received his appointment, see Wu I995, p. 3I2. On the controversy over Wu Guobing's appointment, see Zhongguo renmin zhengzhi xieshang huiyi Sichuan sheng Chongqing shi weiyuanhui, ed., I980, pp. 200-2I2.

II9 Wu I995, p. 3I2.

I 20 “Yushi suoyou fangkonghao yi zu gong shimin yingyong 渝市所有防空壕已足供市民應用” (“All the air-raid shelters in Chongqing are sufficient for the city residents to use"), Shenbao, June I8, I94I; "Yufayuan zhencha dijiao can'an 渝法院偵查地窝慘案” (“Chongqing court investigates tunnel disaster”), Shenbao, June I9, I94I.

I 2 I Chongqing shi renmin fangkong bangongshi, ed., I994, pp. 430-3I.

I 22 He I964, pp. 39-40. Liu Zhi claimed that when he assumed the post of Air Defense Commander, construction for the Great Tunnel was incomplete, and he had tried to speed it up. He argued that he had also made provisions to improve air ventilation in the tunnel. According to him, the Protection Group members tried to forbid people from entering the overcrowded tunnel to no avail, and he only knew of the Disaster the next morning upon his return from assignment on the outskirts of Chongqing. Liu Zhi concluded that by stepping down, he had assumed responsibility for the Disaster on behalf of all the involved personnel. See Liu I966, pp. I56-57. The details of the backroom Nationalist politics over how to handle the Disaster will be difficult, if not impossible, to discover. Chiang Kai-shek's aides and propagandists might have viewed Liu Zhi as a liability, and the Disaster provided them with an opportunity to get rid of him while allowing him a soft landing and placing him in sinecures so that he would not share any insider information with American reporters or other people whom the Nationalist government wanted to keep in the dark. 
shelters. ${ }^{\mathrm{I} 23}$ While expressing his anger and disappointment, Chiang also conveyed his solidarity with his existing team of air defense and medical personnel, opining that the Disaster should not obliterate the efforts of those who had been working hard to serve the nation and people. He urged the Chinese people to learn a lesson from the Disaster and prevent a recurrence of such an event. ${ }^{24}$ The municipal authorities conducted a twenty-one-day Buddhist funeral and memorial service on the site. ${ }^{125}$

After July 3, I94I, all commentaries, editorials, and reports on the Disaster practically ceased. Whether this was the result of public satisfaction with the Report's findings or deliberate muting of responses to the Report on the part of the Nationalist government may never be known. Because various Chinese newspapers had roundly condemned the government for its perceived failure to prevent the Disaster and relieve victims in the aftermath, the first scenario appears more plausible. The active reporting and lively debates on the government's many shortcomings with regard to civil defense and disaster control seemed to have prepared the public for the Report's final verdict, which could be read as a culmination or summary of all that had been mentioned in the newspapers in the preceding weeks. The ire expressed by the wartime press toward the government's failings can be attributed to the popular belief that the Nationalists were capable of doing much better at disaster management and relief, so we may hypothesize that the Chinese people did have faith in the Nationalists. Although the official inquiry emphasized procedural and structural flaws, ordinary Chinese citizens were more concerned about identifying the culprits whom they deemed responsible for the Disaster. ${ }^{126}$

\section{BETHNAL GREEN: SOME COMPARATIVE REFLECTIONS}

The Nationalist government's propaganda strove to emphasize Chinese resilience and unity under intense Japanese air strikes. It downplayed civilian helplessness and ignored the irony that citizens perished in air-raid shelters where they were supposed to be safe from bombing. Unlike the shelter disaster at Bethnal Green on March 3, I943, in which I73 people were crushed to death during an air-raid siren test and that the British government and people agreed had been caused by "a number of people losing their self-control at a particularly unfortunate place and time" (despite differing views on who the culprits were), the Nationalist government and Chinese public held divergent opinions of why the Disaster had occurred. Neither the Nationalist government nor its detractors viewed panic as the leading cause of the Disaster. ${ }^{I 27}$ The Chinese public held the government

I 23 For more details of the "settlement," see Chongqing shi renmin fangkong bangongshi, ed., I994, pp. I50-5I.

I24 “Suidao zhixi can'an shenchahui tichu baogao: junweihui fabiao chuzhi mingling, Jiang weiyuanzhang ye fabiao tongdian 隧道窒息慘案審查會提出報告: 軍委會發表處置命令, 蔣委員長也發表通電” “Tunnel suffocation disaster review committee submits report: military committee issues punishment order, Chairman Jiang also issues telegram”), Zhongyang ribao; Ta Kung Pao; Xinhua ribao, July 3, I94I.

I25 Zhou, ed. 20IIb, p. 37 I.

I 26 This is similar to the Bethnal Green shelter disaster, which will be discussed shortly. See Bourke 2005, p. 236.

I 27 For details of the Bethnal Green shelter disaster, see the official report: Tragedy at Bethnal Green: Report on an Inquiry into the Accident at Bethnal Green Tube Station Shelter (London: The Stationery Office, I999 [I945]). For analyses of the disaster, see Freedman I999, pp. I07-IO; and Bourke 2005, pp. 232-42. As Bourke succinctly puts it, "the nerves of Britons were to remain classified" (p. 234). 
responsible for ineffective disaster prevention, inadequate post-disaster relief, and lackluster efforts to punish the personnel responsible.

Bowing to public opinion, Chiang Kai-shek launched an inquiry and, within a month, issued a report to bring the matter to a close. In contrast, the British government, which feared demoralizing the people and leaking news of "panicking Britons" to Germany, chose not to publish the inquiry report for Bethnal Green until January 20, I945, a few months before the war in Europe ended. ${ }^{128}$ The British government decided to maintain the "myth of the Blitz," which was formed around the Battle of Britain (I940) and depicted national leaders going through thick and thin with the population under the looming threat of a German invasion. ${ }^{\mathrm{I} 9}$ The Nationalist government had no such myth in China, given its callous treatment of civilians in past famines and floods. In striking contrast, the Nationalist government was eager to portray the sacrifices of the Chinese people for the cause of national resistance before a foreign audience. However, to the Chinese public, as Jean R. Freedman eloquently states, "the failure of allies is far more disquieting than the villainy of enemies." ${ }^{20}$ The Nationalist government might have won the press opinion of the West, but in the Disaster, it lost domestic support and trust.

After the Bethnal Green shelter disaster, Britons accused foreigners, Jews, members of the working class, local criminals, and "immoral and selfish" young people of causing a panic and hence the disaster. ${ }^{\mathrm{I} I}$ After the Chongqing Disaster, the Chinese public and "downriver" refugees could have blamed the "backward" residents of Chongqing, but they emotionally and somewhat intuitively took issue with the Nationalist government; the native-outsider divide in the makeshift population of Chongqing seemed to have little influence on the issue. By I94I, the war in China-a war of attrition, as it were-had already been going on for a long time, and the Chinese were anxious, strained, and weary. Their articulation in the newspapers of their anger, grief, and sarcasm about the Disaster revealed their distrust of the government, which had been mired in disrepute for its perceived callousness. The people's reactions to the Disaster were shaped by how they had experienced the war, which was characterized by callous officials breaching river dikes, extracting food from famine-stricken areas, and constructing sub-standard air-raid shelters with the intention of making limited strategic gains or even monetary benefits in wartime.

\section{CONCLUSION}

The imperial Chinese social contract between the state and the people, in which bureaucrats and local officials were obligated to offer at least a modicum of relief to victims of "natural" droughts, famines, and floods, was revised and updated in wartime China in light of new interpretations of disaster and with the advent of increasingly mechanized aerial (and land) warfare. The Nationalist government now had to ensure that enough

\footnotetext{
I 28 "Shelter inquiry report: accident caused by crowd's rush," The Times, January 20, I945

I 29 On the "myth of the Blitz," see Calder I99I.

I30 Freedman I999, p. I Io.

I3I Bourke 2005, pp. 236-37.
} 
preventive measures were taken to minimize civilian casualties from military assaults. In the Great Tunnel Disaster of Chongqing, the government had failed to meet the expectations-entrenched in the social contract of disaster prevention, management, and relief - of the people, who, in their reactions to the Disaster, attempted to renew the contract and remind the government of it. The Chinese public astutely perceived the Disaster as embedded in the social order of structural disadvantages, arguing that responsibility lay with both those who had created that order and those who had benefitted from its activities. ${ }^{132}$ In the end, whether or not the government was culpable in causing the Disaster or fulfilled public expectations for providing adequate air-raid facilities, the inhabitants of Chongqing had nowhere else to go, and their lack of alternatives-their "choosing" to remain in the city-became the "evidence" that the government, its domestic allies, and foreign observers needed, for their respective purposes, to represent the Chinese as a fearless and resilient people under the strains of war.

\section{REFERENCES}

Baldoli, Knapp, and Overy, eds., 20 I I

Baldoli, Claudia, Andrew Knapp, and Richard Overy, eds. Bombing, States, and Peoples in Western Europe I940I945. London: Continuum, 20 I I.

Bankoff 2003

Bankoff, Greg. Cultures of Disaster: Society and Natural Hazard in the Philippines. London and New York: Routledge Curzon, 2003.

Beijing ribao 2015

“Kongxi yihen: Chongqing dahongzha minjian dui Ri suopei de quzhe licheng 空袭遗恨一一重庆大轰炸民间 对日索赔的曲折历程” ““Air-raid sorrows: ordinary folk seek compensation from Japan for the great bombing of Chongqing”), Beijing ribao (Beijing Daily): http://bjrb.bjd.com.cn/html/2015-05/05/content_276842.htm, accessed November 2, 2015 .

Bessel 2015

Bessel, Richard. "Unnatural Deaths." In The Oxford Illustrated History of World War II, ed. Richard Overy, pp. 322-43. New York: Oxford University Press, 2015.

Bourke 2005

Bourke, Joanna. Fear: A Cultural History. London: Virago Press, 2005.

Buchanan 20I 2

Buchanan, Tom. "Comparing British Responses to the Conflicts in Spain and China, I936-39." Contemporary European History 2 I:4 (2012), pp. 533-52.

Calder I99I

Calder, Angus. The Myth of the Blitz. London: Jonathan Cape, I99I.

Chang 20 II

Chang Jui-te. "Bombs Don’t Discriminate? Class, Gender, and Ethnicity in the Air-Raid-Shelter Experiences of the Wartime Chongqing Population." In Beyond Suffering: Recounting War in Modern China, ed. James Flath and Norman Smith, pp. 59-79. Vancouver: UBC Press, 20 II.

Cheng I993

Cheng Yuchen 程雨辰. “Jiang Jieshi yu Chongqing de fangkongdong” 蔣介石與重慶的防空洞 (“Chiang Kaishek and Chongqing's Air-Raid Shelters”), Dang'an shiliao yu yanjiu 4 (I993), pp. 92-94.

Chongqing kangzhan congshu bianzhuan weiyuanhui, ed. I995

Chongqing kangzhan congshu bianzhuan weiyuanhui 重慶抗戰叢書編撰委員會, ed. Kangzhan shiqi Chongqing de fangkong 抗戰時期重慶的防空 (“Chongqing's Air Defense during China's War of Resistance”). Chongqing: Chongqing chubanshe, r995.

Chongqing peidu shishuxi bianweihui, ed. I993 
Chongqing peidu shishuxi bianweihui 重慶陪都史書系編委會, ed. Guomin zhengfu Chongqing peidushi 國民政 府重慶陪都史 (“The History of the Nationalist Provisional Capital of Chongqing”). Chongqing: Xinan shifan daxue chubanshe, I993.

Chongqing shi renmin fangkong bangongshi, ed., I994

Chongqing shi renmin fangkong bangongshi 重慶市人民防空辦公室, ed. Chongqing shi fangkong zhi 重慶市防 空志 (“An Account of Chongqing’s Air Defense”). Chongqing: Xinan shifan daxue chubanshe, I994.

Cook and Gilmartin 2013

Cook, Isabel Brown and Christina Kelley Gilmartin with Yu Xiji, Prosperity's Predicament: Identity, Reform, and Resistance in Rural Wartime China, comp. and ed. Gail Hershatter and Emily Honig. Lanham, MD: Rowman \& Littlefield, 2013.

Dazhong shenghuo Dazhong shenghuo 大衆生活

Ding 2012

Ding Bin 丁斌. “Kangzhan shiqi Chongqing fangkong jianshe yanjiu” 抗戰時期重慶防空建設研究 (“Research on the Construction of Chongqing's Air-Raid Shelters during the War of Resistance”). M.A. thesis. Chongqing Normal University, 2012.

Dudden 2008 Dudden, Alexis. Troubled Apologies among Japan, Korea, and the United States. New York: Columbia University Press, 2008.

Edgerton-Tarpley 2014

Edgerton-Tarpley, Kathryn Jean. "From 'Nourish the People' to 'Sacrifice for the Nation': Changing Responses to Disaster in Late Imperial and Modern China.” The Journal of Asian Studies 73:2 (2014), pp. 447-69.

Edgerton-Tarpley 2008 Edgerton-Tarpley, Kathryn. Tears from Iron: Cultural Responses to Famine in Nineteenth-Century China. Berkeley: University of California Press, 2008.

Freedman I999 Freedman, Jean R. Memory and Culture in Wartime London. Lexington: University of Kentucky Press, I999.

Fuller 2015

Fuller, Pierre. "Changing Disaster Relief Regimes in China: An Analysis using Four Famines between I876 and I962.” Disasters 39:2 (2015), pp. I46-65.

Fuller 20I I

Fuller, Pierre. "Barren Soil, Fertile Minds: North China Famine and Visions of the 'Callous Chinese' Circa I920.” International History Review 33:3 (20I I), pp. 453-72.

Gardiner 20I I

Gardiner, Juliet. “The Blitz Experience in British Society, I940-194I.” In Bombing, States, and Peoples in Western Europe I940-1945, ed. Claudia Baldoli, Andrew Knapp, and Richard Overy, pp. I7 I-83. London: Continuum, $20 I$ I.

Gong’anbu dang'anguan, ed. I99I

Gong’anbu dang’anguan 公安部檔案館, ed. Zai Jiang Jieshi shenbian banian: shicongshi gaoji muliao Tang Zong riji 在蔣介石身邊八年: 侍從室高級幕僚唐縱日記 (“Eight Years at Chiang Kai-shek’s Side: The Diary of a HighLevel Senior Aide Tang Zong”). Beijing: Qunzhong chubanshe, I99I.

Gould I946 Gould, Randall. China in the Sun. New York: Doubleday \& Company, I946.

Grayzel 2012

Grayzel, Susan R. At Home and under Fire: Air Raids and Culture in Britain from the Great War to the Blitz. New York: Cambridge University Press, 2012.

Guo I992

Guo Weibo 郭偉波. “Chongqing dasuidao zhixi can’an qinlij” 重慶大隧道窒息慘案親歷記 (“An Eyewitness Account of the Chongqing Great Tunnel Suffocation Disaster”). In Chongqing dahongzha 重慶大轟炸 (“The Great Bombing of Chongqing”), ed. Xinan shifan daxue lishixi 西南師範大學歷史系 and Chongqing shi dang’anguan 重慶市檔案館, pp. I72-79. Chongqing: Chongqing chubanshe, I992.

Guo 2015

Guo Chuan. "A Contemporary Witness's Journal Account of the r94I Invading Japanese Army’s Fatigue Bombing of Chongqing." Cross-Cultural Communication I I:9 (2015), pp. 9-I3.

Guoji laogong tongxun Guoji laogong tongxun 國際勞工通訊 
Haapamaki 20 I 4

Haapamaki, Michele. The Coming of the Aerial War: Culture and the Fear of Airborne Attack in Inter-War Britain. London and New York: I.B. Tauris, 2014.

Hagiwara 20 I I

Hagiwara, Mitsuru. "The Japanese Air Campaigns in China, I937-I945." In The Battle for China: Essays on the Military History of the Sino-Japanese War of 1937-1945, ed. Mark Peattie, Edward J. Drea, and Hans van de Ven, pp. 237-55. Stanford: Stanford University Press, 20 I I.

Han I968

Han Suyin. Birdless Summer: China Autobiography History. London: Jonathan Cape, I968.

Hartman and Squires, eds. 2006

Hartman, Chester and Gregory D. Squires, eds. There Is No Such Thing as a Natural Disaster: Race, Class, and Hurricane Katrina. New York and London: Routledge, 2006.

He 1964

He Guoguang 賀國光. Bashi zishu八十自述 (“An Autobiography at Eighty”). Taipei: (unknown publisher), I964.

Holman 2014

Holman, Brett. The Next War in the Air: Britain's Fear of the Bomber, I908-194I. Farnham, Surrey: Ashgate, 20 I4.

Howard 2004

Howard, Joshua H. Workers at War: Labor in China's Arsenals, I937-1945. Stanford: Stanford University Press, 2004 .

Janku 2013

Janku, Andrea. “The Internationalisation of Disaster Relief in Early Twentieth-Century China." Berliner Chinahefte 43 (2013), pp. 6-28.

Janku 2012

Janku, Andrea. "From Natural to National Disaster: The Chinese Famine of I928-1930." In Historical Disasters in Context: Science, Religion, and Politics, ed. Andrea Janku, Gerrit J. Schenk, and Franz Mauelshagen, pp. 227-60. New York: Routledge, 2012.

Janku 2009

Janku, Andrea. "Heaven-Sent Disasters' in Late Imperial China: The Scope of the State and Beyond." In Natural Disasters, Cultural Responses: Case Studies toward a Global Environmental History, ed. Christof Mauch and Christian Pfister, pp. 233-64. Lanham, MD: Rowman and Littlefield, 2009.

Kapp I973

Kapp, Robert A. Szechwan and the Chinese Republic: Provincial Militarism and Central Power, I9I I-1938. New Haven and London: Yale University Press, r973.

Lary 2010

Lary, Diana. The Chinese People at War: Human Suffering and Social Transformation, I937-I945. New York: Cambridge University Press, 2010.

Lary 2004

Lary, Diana. “The Waters Covered the Earth: China's War-Induced Natural Disasters.” In War and State Terrorism: The United States, Japan, and the Asia Pacific in the Long Twentieth Century, eds. Mark Selden and Alvin Y. So, pp. I43-70. Lanham, MD: Rowman and Littlefield, 2004.

Lary $200 \mathrm{I}$

Lary, Diana. "Drowned Earth: The Strategic Breaching of the Yellow River Dyke, I938." War and History 8:2 (200I), pp. I9I-207.

Lattimore I990

Lattimore, Owen. China Memoirs: Chiang Kai-shek and the War against Japan. Tokyo: University of Tokyo Press, I990.

Li 2007

Li, Lilian. Fighting Famine in North China: State, Market, and Environmental Decline, I69os-I99os. Stanford: Stanford University Press, 2007.

Lin 2006

Lin Hsiao-ting. Tibet and Nationalist China's Frontier: Intrigues and Ethnopolitics, 1928-49. Vancouver: UBC Press, 2006.

Liu 2010

Liu Fengling 劉鳳玲. “Kangzhan shiqi Chongqing dasuidao can’an yanjiu” 抗戰時期重慶大隧道慘案研究 (“A Study of the Chongqing Great Tunnel Disaster during the War of Resistance”). M.A. thesis. Chongqing Normal University, 20 I0. 
Liu 2010

Liu Xiangshang 劉向上. “Chongqing dahongzha de fangkong heidong” 重慶大轟炸的防空黑洞 (“The Black Hole of the Great Bombing of Chongqing"). Hubei dang'an 4 (2010), pp. 46-47.

Liu 1966

Liu Zhi 劉峙. Wo de huiyi 我的回憶 (“My Reminiscences”). Taipei: Longwen, I966.

Luo 2009

Luo Ling 罗玲. “Kangzhan shiqi Chongqing fangkongdong guanlichu shulun” 抗戰時期重慶防空洞管理處述論 ("A Brief Analysis of the Chongqing Administrative Office of Air-Raid Shelter during the War of Resistance"). Xinan daxue xuebao 5 (2009), pp. I88-92.

Maeda 2009

Maeda, Tetsuo. "Strategic Bombing of Chongqing by Imperial Japanese Army and Naval Forces." In Bombing Civilians: A Twentieth Century History, ed. Yuki Tanaka and Marilyn B. Young, pp. I35-53. New York: The New Press, 2009.

McIsaac 2000

McIsaac, Lee. "The City as Nation: Creating a Wartime Capital in Chongqing." In Remaking the Chinese City: Modernity and National Identity, I900-1950, ed. Joseph W. Esherick, pp. 174-9I. Honolulu: University of Hawai'i Press, 2000.

Meisel 1994

Meisel, Joseph S. "Air Raid Shelter Policy and Its Critics in Britain before the Second World War." Twentieth Century British History 5:3 (I994), pp. 300-319.

Mitter 2013

Mitter, Rana. Forgotten Ally: China's World War II, 1937-1945. Boston and New York: Houghton Mifflin Harcourt, 2013.

Mitter 2010

Mitter, Rana. "Changed by War: The Changing Historiography of Wartime China and New Interpretations of Modern Chinese History." The Chinese Historical Review I7:I (2010), pp. 85-95.

Mittler 2013

Mittler, Barbara. A Continuous Revolution: Making Sense of Cultural Revolution. Cambridge, MA: Harvard University Asia Center, 2013.

Muscolino 2015

Muscolino, Micah S. The Ecology of War in China: Henan Province, the Yellow River, and Beyond, 1938-1950. New York: Cambridge University Press, 2015.

New York Herald Tribune 1939

Overy 2013

Overy, Richard. The Bombing War: Europe 1939-1945. London: Allen Lane, 2013.

Overy, ed., 2015

Overy, Richard, ed. The Oxford Illustrated History of World War II. New York: Oxford University Press, 2015.

Pan 2013

Pan Xun 潘洵. Kangri zhanzheng shiqi Chongqing dahongzha yanjiu 抗日戰爭時期重慶大轟炸研究 (“A Study of the Great Bombing of Chongqing during the War of Resistance"). Beijing: Shangwu yinshuguan, 2013.

Pietz 2015

Pietz, David A. The Yellow River: The Problem of Water in Modern China. Cambridge, MA: Harvard University Press, 2015.

Quarantelli, ed., 2006

Quarantelli, E. L., ed. What Is a Disaster? Perspectives on the Question. London and New York: Routledge, I998.

Russell I922

Russell, Bertrand. The Problem of China. New York: The Century Co., I922.

Schwarcz I997

Schwarcz, Vera. "The Pane of Sorrow: Public Uses of Personal Grief in Modern China." In Social Suffering, eds. Arthur Kleinman, Veena Das, and Margaret Lock, pp. I 19-48. Berkeley: University of California Press, I997. Shenbao

Shenbao 申報

Shilun fenxi

Shilun fenxi 時論分析 
Spector 20II

Spector, Ronald. "The Sino-Japanese War in the Context of World History." In The Battle for China: Essays on the Military History of the Sino-Japanese War of I937-1945, eds. Mark Peattie, Edward J. Drea, and Hans van de Ven, pp. 467-84. Stanford: Stanford University Press, 201 I.

Ta Kung Pao

Ta Kung Pao 大公報

Tan 2015

Tan Gang 譚剛. "Living Underground: Bomb Shelters and Daily Lives in Wartime Chongqing (I937-I945)." Journal of Urban History (20I5). Online First: 0096I442I5579056, first published on 20 April 2015 as doi: IO.II77/0096I442I5579056, pp. I-I7.

Tan 2013

Tan Gang 譚剛. Kangzhan shiqi dahoufang jiaotong yu xibu jingji kaifa 抗戰時期大後方交通與西部經濟開發 ("The Communications of the Rear Area and the Economic Development of Western China in the Period of Anti-Japanese War”). Beijing: Zhongguo shehui kexue chubanshe, 2013.

Taylor 2014

Taylor, Jay. "Chiang Kai-shek and Chinese Modernization.” In Makers of Modern Asia, ed. Ramachandra Guha, pp. 40-64. Cambridge, MA: Harvard University Press, 2014.

The China Weekly Review I94I

The Christian Science Monitor I940

The New York Times I94I and I945

The Sun I94I

The Times I94I

The Washington Post I94I

Tianjia banyuebao

Tianjia banyuebao 田家半月報

Tong 1953

Tong, Hollington K. Chiang Kai-shek. Taipei: China Publishing Company, I953.

Tow 20II

Tow, Edna. "The Great Bombing of Chongqing and the Anti-Japanese War, I937-I945." In The Battle for China: Essays on the Military History of the Sino-Japanese War of 1937-1945, ed. Mark Peattie, Edward J. Drea, and Hans van de Ven, pp. 256-82. Stanford: Stanford University Press, 20I I.

Tragedy at Bethnal Green: Report on an Inquiry into the Accident at Bethnal Green Tube Station Shelter. London: The Stationery Office, I999 [I945].

Wang 2012

Wang, Zheng. Never Forget National Humiliation: Historical Memory in Chinese Politics and Foreign Relations. New York: Columbia University Press, 20I2.

Wei 2014

Wei, Shuge. "News as a Weapon: Hollington Tong and the Formation of the Guomindang Centralized Foreign Propaganda System, I937-I938." Twentieth-Century China 39:2 (2014), pp. I I8-43.

White and Jacoby I946

White, Theodore H., and Annalee Jacoby. Thunder out of China. New York: William Sloane Associates, Inc., I946.

Will I990

Will, Pierre-Etienne. Bureaucracy and Famine in Eighteenth-Century China. Translated by Elborg Forster. Stanford: Stanford University Press, I990.

Wu 1995

Wu Guozhen 吳國楨. Wu Guozhen zhuan 吳國楨傳 (“An Autobiography of Wu Guozhen”). Taipei: Ziyou shibao, I995.

Xiandai gonglun yuekan

Xiandai gonglun yuekan 現代公論月刊.

Xie, ed., 2005

Xie Shilian 謝世廉, ed. Chuan Yu dahongzha 川渝大轟炸 (“The Great Bombing of Sichuan and Chongqing”). Chengdu: Xinan jiaotong daxue chubanshe, 2005.

Xinhua ribao

Xinhua ribao 新華日報. 
Xinhua wang 2015

“Chongqing juxing Chongqing dahongzha jinian huodong 重庆举行 “重庆大轰炸”纪念活动” ““Chongqing holds commemorative service for the great bombing of Chongqing”), Xinhua wang 新华网 (Xinhua News Agency): http://news.xinhuanet.com/local/2015-06/05/c_I II55283I4.htm, accessed November 2, 2015.

$\mathrm{Xu} 200 \mathrm{I}$

Xu Jianming 徐建明. “Chongqing dasuidao zhixi can’an siwang renshu kaoxi” 重慶大隧道窒息慘案死亡人數 考析 (“An Analysis of the Death Toll of the Chongqing Great Tunnel Suffocation Disaster”). Kangri zhanzheng yanjiu 3 (200I), pp. I28-37.

Yoshida 2006

Yoshida, Takashi. The Making of the "Rape of Nanking": History and Memory in Japan, China, and the United States. New York: Oxford University Press, 2006.

Zhongguo renmin zhengzhi xieshang huiyi Sichuan sheng Chongqing shi weiyuanhui, ed., I980 Zhongguo renmin zhengzhi xieshang huiyi Sichuan sheng Chongqing shi weiyuanhui 中國人民政治協商會 議四川省重慶市委員會, ed. Sichuan wenshi ziliao xuanji 四川文史資料選輯 (“A Selection of Information on Sichuan's Literature and History”), vol. 7. Chengdu: Sichuan renmin chubanshe, I980.

Zhongguo renmin zhengzhi xieshang huiyi Sichuan sheng Chongqing shi weiyuanhui, ed., I983 Zhongguo renmin zhengzhi xieshang huiyi Sichuan sheng Chongqing shi weiyuanhui 中國人民政治協商會 議四川省重慶市委員會, ed. Sichuan wenshi ziliao xuanji 四川文史資料選輯 (“A Selection of Information on Sichuan's Literature and History”), vol. I2. Chengdu: Sichuan renmin chubanshe, I983.

Zhongguo renmin zhengzhi xieshang huiyi Sichuan sheng Chongqing shi weiyuanhui, ed., I985 Zhongguo renmin zhengzhi xieshang huiyi Sichuan sheng Chongqing shi weiyuanhui 中國人民政治協商會 議四川省重慶市委員會, ed. Chongqing kangzhan jishi 重慶抗戰紀事 (“The Chronicle of Chongqing’s War of Resistance"). Chongqing: Chongqing chubanshe, I985.

Zhongguo renmin zhengzhi xieshang huiyi Sichuan sheng Chongqing shi weiyuanhui, ed., I993 Zhongguo renmin zhengzhi xieshang huiyi Sichuan sheng Chongqing shi weiyuanhui 中國人民政治協商會 議四川省重慶市委員會, ed. Chongqing wenshi ziliao 重慶文史資料 (“A Selection of Information on Chongqing's Literature and History”), vol. 43. Chongqing: Xinan shifan daxue chubanshe, I993.

Zhongguo xinwen wang 2015

“Chongqing dahongzha shouhaizhe guan yuebing: dui Ri suopei shiyue jiang zai qihang 重庆大轰炸受害者观 阅兵 对日索赔十月将再 “起航” (“Victims of the great bombing of Chongqing attend military parade: seeking compensation from Japan again in October”), Zhongguo xinwen wang 中国新闻网 (China News Service): http:// www.chinanews.com/gn/2015/09-03/7504747.shtml, accessed November 2, 2015.

Zhongyang ribao Zhongyang ribao 中央日報.

Zhou, ed., 20 IIa Zhou Yong 周勇, ed. Zhengren zhengyan 證人證言 (“Testimonies of Witnesses”). Chongqing: Chongqing chubanshe, 20 II.

Zhou, ed., $201 \mathrm{Ib}$ Zhou Yong 周勇, ed. Chongqing dahongzha dang'an wenxian 重慶大轟炸檔案文獻 (“Archival Documents on the Great Bombing of Chongqing”). Chongqing: Chongqing chubanshe, 20 Ir.

Zhou, Chang, and Gong 2014

Zhou Yong, Vincent K. L. Chang, and Xiaohui Gong. "Recalling the War in China: The Dahoufang Project in Chongqing and the Restoration of a Legacy." Frontiers of History in China 9:4 (20I4), pp. 6I I-27.

Zurndorfer 2013 Zurndorfer, Harriet. "Wartime Refugee Relief in Chinese Cities and Women's Political Activism, I937-1940." In New Narratives of Urban Space in Republican Chinese Cities: Emerging Social, Legal, and Governance Orders, ed. Billy K. L. So and Madeleine Zelin, pp. 65-9r. Leiden and Boston: Brill 2013. 